\title{
Design, Synthesis and Cytotoxicity Evaluation of Structural Analogues of Imatinib
}

\author{
Aliaksandr Faryna, Elena Kalinichenko ", Olga Avdoshko, Alla Belko \\ Institute of Bioorganic Chemistry, National Academy of Sciences of Belarus, Minsk, Belarus
}

Email address:

kalinichenko@iboch.bas-net.by (E. Kalinichenko)

${ }^{*}$ Corresponding author

\section{To cite this article:}

Aliaksandr Faryna, Elena Kalinichenko, Olga Avdoshko, Alla Belko. Design, Synthesis and Cytotoxicity Evaluation of Structural Analogues of Imatinib. Journal of Drug Design and Medicinal Chemistry. Vol. 3, No. 2, 2017, pp. 27-31. doi: 10.11648/j.jddmc.20170302.12

Received: February 28, 2017; Accepted: April 21, 2017; Published: May 19, 2017

\begin{abstract}
Several novel imatinib structure analogues were synthesized. Antiproliferative activity testing on various leukemic cell lines showed 1-2 fold less activity against K562 cells compared to imatinib. Autodock Vina's docking studies predicted no differences in binding affinity of the titled compounds while positive relationship between activity and calculated lipophilicity was found. Further imatinib structure optimization pathways were evaluated.
\end{abstract}

Keywords: Imatinib, Structural Analogues, Protein Kinase Inhibitor, Molecule Design, Anticancer

\section{Introduction}

Chronic myelogenous leukemia is a common type of blood cancer comprising from reciprocal chromosomal translocation between chromosome 9 and chromosome 22, which results in the formation of fusion BCR-ABL gene coding specific protein: bcr-abl tyrosinekinase [1]. High and deregulated kinase activity of the protein causes uncontrolled leukemic cell growth by altering of cell signaling pathways and apoptosis program disturbance [2].

Imatinib is the 2-phenyl amino pyrimidine derivative and a current first-line treatment for CML [3]. Imatinib is a selective inhibitor of bcr-abl tyrosinekinase and able to bind to ATP-pocket, thus blocking biological functions of the protein [4]. However, clinical use of imatinib is limited, to a certain degree, by patients' intolerance or drug resistance caused by the formation of various mutant forms of bcr-abl tyrosinkinase. Point mutations alter the structure of the active site of the protein significantly decreasing the imatinib binding ability [5].
In this study, we made an attempt to develop novel structural analogues of imatinib with enhanced inhibitory activity against CML using the modification of terminal phenyl ring as the design approach.

\section{Materials and Methods}

Target compounds $4 \mathrm{a}-\mathrm{f}$ were obtained by the reaction of 4-Methyl-N3-[4-(3-pyridinyl)-2-pyrimidinyl]-1,3-benzenedia mine 1 with acid chlorides of corresponding benzoic acid derivatives 3a-f. Starting amine 1 was synthesized as described earlier [6]. Acid chlorides 2a-f were prepared using thionyl chloride and DMF as a catalyst. Final condensation step was carried out in chloroform. The synthetic route is summarized in Figure 1. Compounds were tested for their anti-proliferative activity against several various cell lines using MTT-test. 


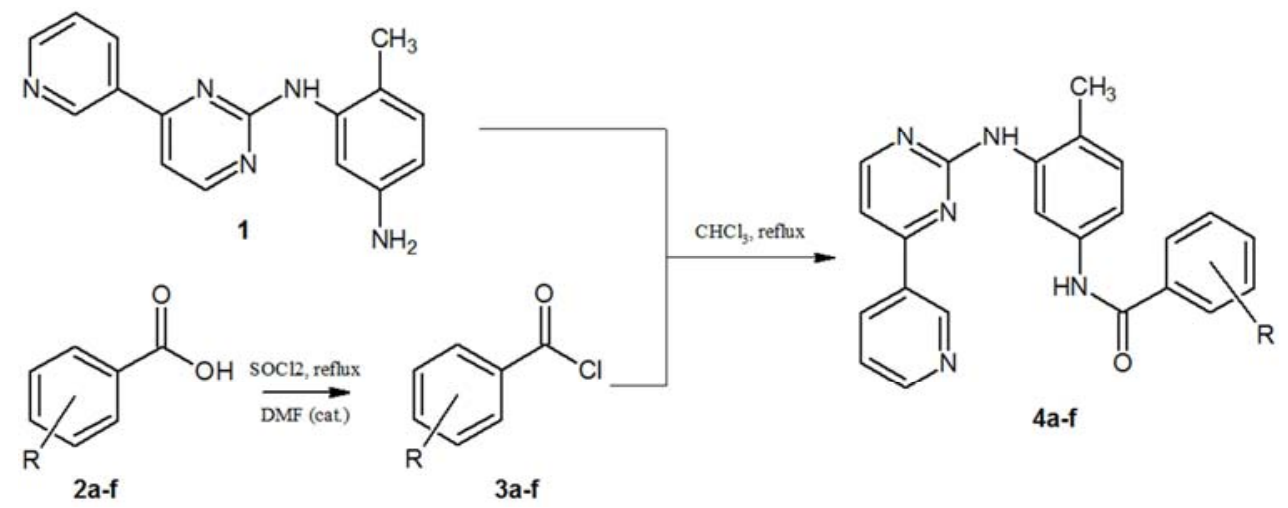

Figure 1. Synthetic route to imatinib derivatives.

\section{Results and Discussion}

\subsection{Chemistry}

Six imatinib analogues 4a-f were synthesized with the compounds $4 \mathrm{a}$-e being not previously described. Structures and yields of title compounds are shown in Table 1 .
Anti-proliferative activity was tested compared to substances with known inhibitory activity: imatinib and nilotinib. Imatinib derivative 5 not containing N-methylpiperazine substituent was also taken as a reference as the methylpiperazine group is known to enhance the imatinib activity by adding more protein-ligand interactions and improving solubility. Structures of references are shown in Figure 2.

Table 1. Structures and yields of title compounds.

\begin{tabular}{lllll}
\hline Compound & R & Chemical formula & M.W. & Total yield, \% \\
\hline $4 \mathrm{a}$ & $o-\mathrm{F}$ & $\mathrm{C}_{23} \mathrm{H}_{18} \mathrm{FN}_{5} \mathrm{O}$ & 76 \\
$4 \mathrm{~b}$ & $m-\mathrm{F}$ & $\mathrm{C}_{23} \mathrm{H}_{18} \mathrm{FN}_{5} \mathrm{O}$ & 399.43 \\
$4 \mathrm{c}$ & $p-\mathrm{F}$ & $\mathrm{C}_{23} \mathrm{H}_{18} \mathrm{FN}_{5} \mathrm{O}$ & \\
$4 \mathrm{~d}$ & $p-\mathrm{Br}$ & $\mathrm{C}_{23} \mathrm{H}_{18} \mathrm{BrN}_{5} \mathrm{O}$ & 460.34 & 74 \\
$4 \mathrm{e}$ & $o-\mathrm{OAc}$ & $\mathrm{C}_{25} \mathrm{H}_{21} \mathrm{~N}_{5} \mathrm{O}_{3}$ & 439.48 & 68 \\
$4 \mathrm{f}$ & $o-\mathrm{OH}$ & $\mathrm{C}_{23} \mathrm{H}_{19} \mathrm{~N}_{5} \mathrm{O}_{2}$ & 367.44 \\
\hline
\end{tabular}<smiles>Cc1ccc(C(=O)Nc2ccc(CN3CCN(C)CC3)cc2)cc1Nc1nccc(-c2cccnc2)n1</smiles>

imatinib<smiles>Cc1cn(-c2cc(NC(=O)c3ccc(C)c(Nc4nccc(-c5cccnc5)n4)c3)cc(C(F)(F)F)c2)cn1</smiles>

nilotinib<smiles>Cc1ccc(NC(=O)c2ccccc2)cc1Nc1nccc(-c2cccnc2)n1</smiles>

5

Figure 2. Reference compound structures.

\subsection{Biological Activity}

For K-562 human myelogenous leukemia cell line, the results of anti-proliferative studies for known inhibitors corresponded with published data [7]. Compounds 4a-f showed 1-2-fold less activity compared to imatinib. Worst results were obtained for compounds containing the para-halogen substituent $(4 \mathrm{c}-\mathrm{d})$. The most active $\left(\mathrm{IC}_{50}=6.7\right.$ $\mu \mathrm{M})$ was the meta-fluorine derivate $4 \mathrm{~b}$ being even more effective than compound 5 . That makes promising adding the $\mathrm{N}$-methylpiperazine fragment to the initial structure of $4 \mathrm{~b}$. Summary of biological activity testing is shown in the Table 2.

Table 2. Antiproliferative activity of $4 a-f$.

\begin{tabular}{|c|c|c|c|c|c|c|}
\hline \multirow{2}{*}{ Compound } & \multicolumn{6}{|c|}{$\mathrm{IC}_{50}, \mu \mathrm{M}$} \\
\hline & K562 & MOLT-4 & THP-1 & MOLT-3 & HL-60 & KG-1 \\
\hline Imatinib & 0.45 & & 30 & 0.75 & $50(6.2)$ & 50 \\
\hline Nilotinib & $<0.1$ & 14.5 & 35 & 0.90 & 55 & 70 \\
\hline $4 a$ & 40 & 12.2 & 80 & 65 & 100 & 100 \\
\hline $4 b$ & 6.7 & 30.2 & & & & \\
\hline $4 c$ & 112 & n.d.* & & & & \\
\hline
\end{tabular}




\begin{tabular}{|c|c|c|c|c|c|c|}
\hline \multirow{2}{*}{ Compound } & \multicolumn{6}{|c|}{$\mathrm{IC}_{50}, \boldsymbol{\mu M}$} \\
\hline & K562 & MOLT-4 & THP-1 & MOLT-3 & HL-60 & KG-1 \\
\hline $4 d$ & n.d. & n.d. & & & & \\
\hline $4 \mathrm{e}$ & $20(26)$ & $95(68)$ & & 100 & 85 & 100 \\
\hline $4 \mathrm{f}$ & 57.1 & 17.4 & & & & \\
\hline 5 & 19.3 & & & & & \\
\hline
\end{tabular}

n.d. - not detected

\subsection{Docking Studies}

To investigate differences in experimental biological data we have performed docking studies of protein-ligand complexes of $4 \mathrm{a}-\mathrm{f}$ with tyrosinekinase using Autodock Vina [8]. To validate docking procedure, structures of imatinib, nilotinib and compound 5 were used as references. In our case, docking results depended on the initial 3-dimenstional structures of ligands. We started from the structures obtained from two sources: Cactus [9] and Molview [10]. In the case of Cactus-structures, docked pose of imatinib didn't match experimental X-ray data for the imatinib-kinase complex.

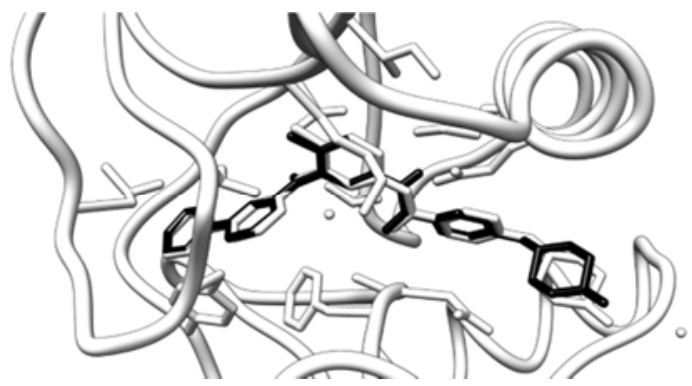

Figure 3. Docked pose of imatinib (black) compared to experimental data (white) of imatinib-kinase complex.

Table 3. Autodock Vina docking results.

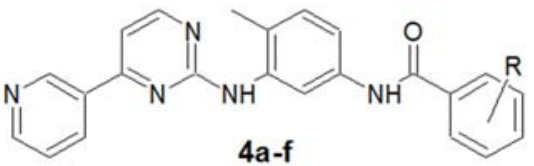

\begin{tabular}{|c|c|c|}
\hline Compound & $\mathbf{R}$ & Autodock Vina Score* \\
\hline $4 \mathrm{a}$ & $o-\mathrm{F}$ & -12.6 \\
\hline $4 b$ & $m-\mathrm{F}$ & -12.7 \\
\hline $4 c$ & $p-\mathrm{F}$ & -12.6 \\
\hline $4 d$ & $p-\mathrm{Br}$ & -12.7 \\
\hline $4 \mathrm{e}$ & $o$-OAc & -12.7 \\
\hline $4 \mathrm{f}$ & $o-\mathrm{OH}$ & -12.6 \\
\hline nilotinib & - & -13.9 \\
\hline imatinib & - & -13.3 \\
\hline
\end{tabular}

* - dimensionless value, less value means better binding affinity

Using Molview-generated structures the uncommon docked position of pyrimidine system for structures $4 \mathrm{a}-\mathrm{c}$ was observed. Due to these facts, we applied energy minimization on the initial ligand structures with GAFF and MMFF94s force fields using OpenBabel [11]. Docked poses of GAFF-minimized Molview structures had no visual problems and were considered as valid results (Figure 3). Final docked poses of imatinib and nilotinib were identical to experimental data. There also was a correlation between estimated and experimental binding affinities of reference structures with nilotinib predicted to be more active than imatinib and imatinib to be more active than compound 5. The other fact is that there was no significant difference in predicted binding affinities for title compounds $4 \mathrm{a}-\mathrm{f}$ (Table 3 ). It may be due to the changings in protein structure or more likely the distinction of ADME properties between the compounds.

To check this assumption partition coefficients $(\log \mathrm{P})$ of tested compounds were predicted using Molinspiration [12] (Table 4). The results showed good linear correlation with experimental $\mathrm{IC}_{50}$ values $\left(\mathrm{R}^{2}=0.69\right)$. Least lipophilic 4-bromo imatinib derivative $4 \mathrm{~d}$ has showed no inhibitory activity in biological tests. On the contrary, imatinib was an excellent inhibitor with the greatest calculated lipophilicity. This correlation was more significant when the structures of $4 \mathrm{~b}$ and 4f were excluded $\left(\mathrm{R}^{2}=0.91\right)$ that may be explained by additional protein-ligand interactions of the terminal phenyl ring region of $4 \mathrm{a}$ and $4 \mathrm{f}$ compared to imatinib.

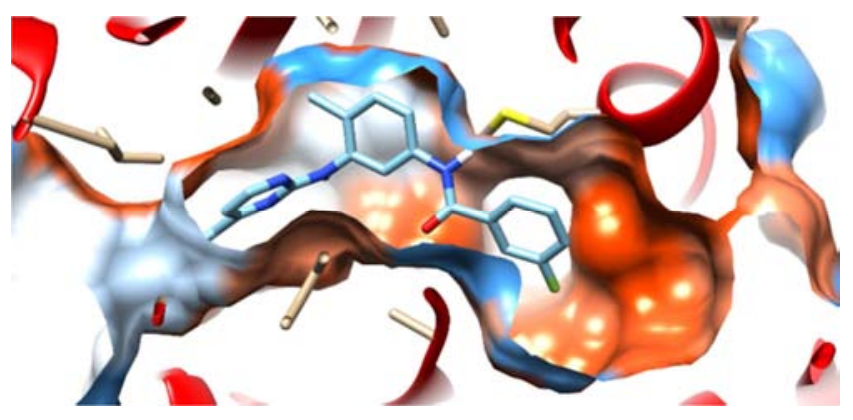

Figure 4. The fluorine atom of $4 b$ resting in hydrophobic pocket of the allosteric site of abl-kinase. 
For $4 \mathrm{a}$ it is likely the fluorine atom at the meta position is resting in the nearby hydrophobic pocket thus increasing binding affinity (Figure 3 ). In the case of $4 \mathrm{f}$ interactions of the hydroxyl group cannot be explained straightforward. Having relatively poor lipophilicity $4 \mathrm{f}$ showed comparable to compound 5 activity. Probably interactions of hydroxyl interfere with some sort of steric hindrance.

Table 4. Predicted partition coefficient values $(\log P)$ for the compounds.

\begin{tabular}{|c|c|c|c|c|c|c|c|c|}
\hline Compound & $4 a$ & $4 b$ & $4 c$ & 4d & $4 e$ & $4 f$ & 5 & imatinib \\
\hline predicted $\log \mathrm{P}$ & 4.31 & 4.33 & 4.36 & 5 & 4.25 & 4.68 & 4.19 & 3.89 \\
\hline $\mathrm{IC}_{50}, \mathrm{um}$ & 40 & 6.7 & 112 & $300 *$ & 26 & 57.1 & 19.3 & 0.4 \\
\hline
\end{tabular}

* - $\mathrm{IC}_{50}$ value was assumed

Summarizing, one may point out the most promising directions for imatinib structure modifications to enhance it's inhibitory activity. Firstly, terminal phenyl ring of imatinib structure may be expanded by the introduction of meta-substituents of different nature. Secondly, the phenyl ring can be replaced with 5-membered aromatic system with the hydrophilic group in second position relative to the amide bond.

\section{Conclusions}

Several novel structural analoguess of imatinib was synthesized. Although better inhibitory activity of the title compounds compared to imatinib was not achived, docking studies and calculated lipophilicity along with $\mathrm{IC}_{50}$ values revealed possible imatinib structure optimization pathways.

\section{Experimental}

All reagents were purchased from commercial sources and used without any additional purification. $1 \mathrm{H}$ NMR spectra were recorded on Brucker NMR $400 \mathrm{MHz}$ spectrometer. The chemical shifts, $\delta$, were recorded relative to tetramethylsilane as an internal standard. MS were recorded on HPLC/MS Accela with LCQ Fleet detector with Thermo Electron 3D quadrupole ion trap using ESP ionization. The reactions were monitored by TLC using silica gel plates Merk «DC-Plasticfolien Kieselgel 60 F 254» with the chloroform-methanol mixture.

\subsection{Docking}

Crystal structure of C-Abl kinase domain in complex with imatinib was taken from PDB entry 1IEPB. Chimera [13] was used for the visualization of the results as well as for the preparation of the receptor and ligands. Autodock Vina's exhaustiveness of search was set to 24 .

\subsection{Antiproliferative Activity}

The effects of the compounds on cell growth were evaluated using the MTT assay. Cell lines obtained from the Institute of Cytology RAS were cultivated in RPMI 1640 media with 10\% (20\% for MOLT-3) Hyclone fetal bovine serum. Cells were plated in 96-well plates at a concentration of $110^{4}$ cells/well, and incubated for $24 \mathrm{~h}$ at $37^{\circ} \mathrm{C}$ followed by addition of target compounds at various concentrations for $48 \mathrm{~h}$. Then, $20 \mathrm{~mL}$ MTT $(5 \mathrm{mg} / \mathrm{mL})$ was added to each well and incubated for $4 \mathrm{~h}$ at $37^{\circ} \mathrm{C}$. The plates were centrifuged and the supernatant was removed. $150 \mu \mathrm{L}$ DMSO was added to each well to dissolve MTT crystals, and the absorbance values for each well were read by a microplate reader at $490 \mathrm{~nm}$. For cell viability data 4 parameter logistics regression was applied and $\mathrm{IC}_{50}$ was estimated.

\subsection{Synthesis}

2-fluoro-N-(4-methyl-3-((4-(pyridine-3-yl)pyrimidine-2-yl )amino)phenyl)benzamide (4a).

To $200 \mathrm{mg}(0,5 \mathrm{mmol})$ of 2-fluoro benzoic acid $1 \mathrm{ml}$ of thionyl chloride and one drop of DMF were added. Reaction mixture was heated to $50^{\circ} \mathrm{C}$ and was maintained at this temperature for 8 hours. Excess of thionyl chloride was removed by reduced pressure distillation. To the residue 138,7 $\mathrm{mg} \quad(0,5 \mathrm{mmol})$ of $\mathrm{N}$-(5-amino-2-methylphenyl)-4-(3pyrydyl-)-2-pyrymidineamine 1 in $5 \mathrm{ml}$ of chloroform was added and the mixture was refluxed for $12 \mathrm{~h}$. The solid was filtered and washed with chloroform. The crude product was purified by column chromatography (methanol-chloroform 1:20), giving $148 \mathrm{mg}$ of yellowish solid (yield 74\%).

MS (m/z): 400,1[MH+]; ${ }^{1} \mathrm{H}$ NMR (500 MHz, DMSO-d6) $\delta$ ppm $10.38(\mathrm{~s}, 1 \mathrm{H}) 9.27(\mathrm{~s}, 1 \mathrm{H}) 9.00(\mathrm{~s}, 1 \mathrm{H}) 8.64-8.74(\mathrm{~m}, 1$ H) $8.51(\mathrm{~d}, J=5.13 \mathrm{~Hz}, 1 \mathrm{H}) 8.47(\mathrm{dd}, J=8.01,1.60 \mathrm{~Hz}, 1 \mathrm{H})$ $8.01-8.12(\mathrm{~m}, 1 \mathrm{H}) 7.66(\mathrm{t}, J=7.05 \mathrm{~Hz}, 1 \mathrm{H}) 7.54-7.60(\mathrm{~m}, 1$ H) $7.52(\mathrm{dd}, J=8.01,4.81 \mathrm{~Hz}, 1 \mathrm{H}) 7.40$ - $7.46(\mathrm{~m}, 2 \mathrm{H}) 7.29$ $7.39(\mathrm{~m}, 2 \mathrm{H}) 7.21(\mathrm{~d}, J=8.33 \mathrm{~Hz}, 1 \mathrm{H}) 2.23(\mathrm{~s}, 3 \mathrm{H})$.

Compounds $4 \mathrm{~b}-\mathrm{f}$ were prepared as described above.

3-fluoro-N-(4-methyl-3-((4-(pyridine-3-yl)pyrimidine-2-yl )amino)phenyl)benzamide (4b).

MS (m/z): 400,1[MH+]; 1H NMR (500 MHz, DMSO-d6) $\delta$ ppm $10.28(\mathrm{~s}, 1 \mathrm{H}) 9.22-9.36(\mathrm{~m}, 1 \mathrm{H}) 8.95-9.04(\mathrm{~m}, 1 \mathrm{H})$ $8.64-8.77(\mathrm{~m}, 1 \mathrm{H}) 8.53-8.59(\mathrm{~m}, 1 \mathrm{H}) 8.47-8.53(\mathrm{~m}, 1 \mathrm{H})$ $8.05-8.15(\mathrm{~m}, 1 \mathrm{H}) 7.80(\mathrm{~d}, J=7.69 \mathrm{~Hz}, 1 \mathrm{H}) 7.73-7.78(\mathrm{~m}$, $1 \mathrm{H}) 7.52$ - $7.61(\mathrm{~m}, 1 \mathrm{H}) 7.38$ - $7.49(\mathrm{~m}, 1 \mathrm{H}) 7.21(\mathrm{~d}, J=8.01$ $\mathrm{Hz}, 1 \mathrm{H}) 2.22$ (s, $1 \mathrm{H})$.

4-fluoro-N-(4-methyl-3-((4-(pyridine-3-yl)pyrimidine-2-yl )amino)phenyl)benzamide (4c).

MS (m/z): 400,2[MH+]; 1H NMR (500 MHz, DMSO-d6) $\delta$ ppm $10.23(\mathrm{~s}, 1 \mathrm{H}) 9.27(\mathrm{~s}, 1 \mathrm{H}) 8.98(\mathrm{~s}, 1 \mathrm{H}) 8.68(\mathrm{~d}, J=3.53$ $\mathrm{Hz}, 1 \mathrm{H}) 8.51(\mathrm{~d}, J=5.13 \mathrm{~Hz}, 1 \mathrm{H}) 8.47(\mathrm{~d}, J=8.01 \mathrm{~Hz}, 1 \mathrm{H})$ $8.06-8.11(\mathrm{~m}, 1 \mathrm{H}) 8.03(\mathrm{dd}, J=8.49,5.61 \mathrm{~Hz}, 2 \mathrm{H}) 7.52(\mathrm{dd}$, $J=7.69,4.81 \mathrm{~Hz}, 1 \mathrm{H}) 7.47(\mathrm{~d}, J=8.01 \mathrm{~Hz}, 1 \mathrm{H}) 7.42(\mathrm{~d}, J=$ $4.81 \mathrm{~Hz}, 1 \mathrm{H}) 7.33-7.39(\mathrm{~m}, 2 \mathrm{H}) 7.21(\mathrm{~d}, J=8.01 \mathrm{~Hz}, 1 \mathrm{H})$ $2.22(\mathrm{~s}, 3 \mathrm{H})$.

3-bromo-N-(4-methyl-3-((4-(pyridine-3-yl)pyrimidine-2-yl 
)amino)phenyl)benzamide (4d).

MS (m/z): 460,1 and 462,1[MH+]; 1H NMR (500 MHz, DMSO-d6) $\delta$ ppm $10.31(\mathrm{~s}, 1 \mathrm{H}) 9.29(\mathrm{~s}, 1 \mathrm{H}) 8.99(\mathrm{~s}, 1 \mathrm{H})$ $8.65-8.73(\mathrm{~m}, 1 \mathrm{H}) 8.52(\mathrm{~d}, J=5.13 \mathrm{~Hz}, 1 \mathrm{H}) 8.46-8.51(\mathrm{~m}$, $1 \mathrm{H}) 8.07-8.14(\mathrm{~m}, 1 \mathrm{H}) 7.92(\mathrm{~d}, J=8.66 \mathrm{~Hz}, 2 \mathrm{H}) 7.75(\mathrm{~d}, J=$ $8.66 \mathrm{~Hz}, 2 \mathrm{H}) 7.51-7.56(\mathrm{~m}, 1 \mathrm{H}) 7.46-7.50(\mathrm{~m}, 1 \mathrm{H}) 7.44$ (d, $J=5.13 \mathrm{~Hz}, 1 \mathrm{H}) 7.24(\mathrm{~s}, 1 \mathrm{H}) 2.24(\mathrm{~s}, 3 \mathrm{H})$.

3-O-acetyl-N-(4-methyl-3-((4-(pyridine-3-yl)pyrimidine-2 -yl)amino)phenyl)benzamide (4e).

MS (m/z): 564,0[MH+]; 1H NMR (500 MHz, DMSO-d6) $\delta$ ppm 10.36 (s, $1 \mathrm{H}) 9.51$ (d, $J=1.60 \mathrm{~Hz}, 1 \mathrm{H}) 9.37$ (br. s., $1 \mathrm{H}$ ) $9.18(\mathrm{~d}, J=8.33 \mathrm{~Hz}, 1 \mathrm{H}) 9.02(\mathrm{~d}, J=4.81 \mathrm{~Hz}, 1 \mathrm{H}) 8.65(\mathrm{~d}, J$ $=5.13 \mathrm{~Hz}, 1 \mathrm{H}) 8.35(\mathrm{~s}, 1 \mathrm{H}) 8.13(\mathrm{dd}, J=8.17,5.61 \mathrm{~Hz}, 1 \mathrm{H})$ 8.05 (br. s., $1 \mathrm{H}) 7.72$ (dd, $J=7.69,1.28 \mathrm{~Hz}, 1 \mathrm{H}) 7.65$ (d, $J=$ $5.13 \mathrm{~Hz}, 1 \mathrm{H}) 7.56(\mathrm{td}, J=7.85,1.60 \mathrm{~Hz}, 1 \mathrm{H}) 7.36-7.42(\mathrm{~m}$, $2 \mathrm{H}) 7.24(\mathrm{~d}, J=8.01 \mathrm{~Hz}, 1 \mathrm{H}) 7.21(\mathrm{~d}, J=8.33 \mathrm{~Hz}, 1 \mathrm{H}) 2.22$ (s, $3 \mathrm{H}) 2.15$ (s, $3 \mathrm{H})$.

3-hydroxy-N-(4-methyl-3-((4-(pyridine-3-yl)pyrimidine-2yl)amino)phenyl)benzamide (4f).

MS (m/z): 398,1[MH+]; 1H NMR (500 MHz, DMSO-d6) $\delta$ ppm 10.47 (s, $1 \mathrm{H}) 9.51(\mathrm{~d}, J=1.60 \mathrm{~Hz}, 1 \mathrm{H}) 9.32$ (s, $1 \mathrm{H}) 9.16$ $(\mathrm{dt}, J=8.33,1.60 \mathrm{~Hz}, 1 \mathrm{H}) 9.00(\mathrm{dd}, J=5.45,1.28 \mathrm{~Hz}, 1 \mathrm{H})$ $8.65(\mathrm{~d}, J=5.13 \mathrm{~Hz}, 1 \mathrm{H}) 8.34(\mathrm{~s}, 1 \mathrm{H}) 8.07-8.12(\mathrm{~m}, 2 \mathrm{H})$ $8.04(\mathrm{dd}, J=7.85,1.44 \mathrm{~Hz}, 1 \mathrm{H}) 7.64(\mathrm{~d}, J=5.13 \mathrm{~Hz}, 1 \mathrm{H})$ $7.37-7.45(\mathrm{~m}, 2 \mathrm{H}) 7.24(\mathrm{~d}, J=8.33 \mathrm{~Hz}, 1 \mathrm{H}) 7.03(\mathrm{dd}, J=$ 8.33, $0.96 \mathrm{~Hz}, 1 \mathrm{H}) 6.92-6.98(\mathrm{~m}, 1 \mathrm{H}) 2.24(\mathrm{~s}, 3 \mathrm{H})$.

\section{Acknowledgements}

The financial support of this work within the research project number 4.20 of Chem Pharm Synthesis Program, National Academy of Sciences of Belarus, is highly acknowledged.

\section{References}

[1] M. A. Lichtman, J. L Lieveld. "Chronic myelogenous leukemia and related disorders", in Williams hematology, 6th ed., New York: McGraw-Hill, 2001, pp. 1125-36.
[2] T. G. Lugo, A. M. Pendergast, A. J. Muller, O. N. Witte, "Tyrosine kinase activity and transformation potency of bcr-abl oncogene products", Science, vol. 247, pp. 1079-1082, 1990.

[3] M. Baccarani, F. Castagnetti, G. Gugliotta, G. Rosti, "A review of the European LeukemiaNet recommendations for the management of CML", Ann. Hematol., vol. 94, suppl. 2, pp. 141-147, 2015.

[4] M. J. Eck, P. W. Manley. "The Interplay of Structural Information and Functional Studies in Kinase Drug Design: Insights from BCR-Abl.” Current Opinion in Cell Biology, vol. 21.2, pp. 288-295, 2009.

[5] F. Lee, A. Fandi, M. Voi, "Overcoming kinase resistance in chronic myeloid leukemia", Int. J. Biochem. Cell Biol, vol. 40(3), pp: 334-343, 2008.

[6] V. E. Agabekov, et al. "Preparation of 4-[(4-methyl-1-pyperazinil)-methyl]-N-[4-methyl-3-\{[4-(3-py ridyl)-2-pyrimidinyl]-amino phenyl]benzamide sulfonate", pat. 17047, Rep. of Belarus, 30.04.2013.

[7] H. G. Jørgensen, E. K. Allan, N. E. Jordanides, J. C. Mountford, T. L. Holyoake, Allan "Nilotinib exerts equipotent antiproliferative effects to imatinib and does not induce apoptosis in CD34+ CML cells", Blood, vol. 109(9), pp 4016-4019, 2007.

[8] O. Trott, A. J. Olson, “AutoDock Vina: improving the speed and accuracy of docking with a new scoring function, efficient optimization and multithreading", J. Comp. Chem., vol. 31, pp. 455-461, 2010.

[9] https://cactus.nci.nih.gov/translate/

[10] http://molview.org/

[11] N. M. O'Boyle, M. Banck, C. A. James, C. Morley, T. Vandermeersch, G. R. Hutchison, Open Babel: An open chemical toolbox", J. Cheminf., 3: 33, 2011.

[12] http://www.molinspiration.com/cgi-bin/properties.

[13] E. F. Pettersen, T. D. Goddard, C. C. Huang, G. S. Couch, D. M. Greenblatt, E. C. Meng, T. E. Ferrin, "UCSF Chimera - a visualization system for exploratory research and analysis", J. Comp. Chem., vol. 25(13), pp. 1605-1612, 2004. 